\title{
Characteristics of Yakju fermented using different commercial yeasts
}

\author{
Jeong-Sil Choi, Yoo-Deok Park, Chan-Woo Kim, Seok-Tae Jeong* \\ Fermented Food Science Division, National Institute of Agricultural Sciences, RDA, Wanju 55365, Korea
}

\section{시판 효모의 종류를 달리한 약주의 품질특성}

\author{
최정실 · 박유덕 · 김찬우 · 정석태* \\ 국립농업과학원 발효가공식품과
}

\begin{abstract}
This study was conducted to investigate the characteristics of Yakju fermented using different 7 commercial yeasts; La parisienne (black), La parisienne (red), Fermivin, RC212, K1-V1116, D47, and EC1118. After completion of fermentation, the total acid content in Yakju ranged from 0.26 to $0.40 \%$; the lowest and highest values corresponded to fermentation using La parisienne (red) and EC1118, respectively. The amino acidity of the different Yakju samples varied significantly in the range of 2.49 to 5.50. The Yakju fermented with K1-V1116, La parisienne (black), La parisienne (red) showed high amino acidity levels of 5.59, 5.55 and 5.34, respectively, but that fermented with Fermivin showed a low level of 2.49. EC1118 seemed to be most suitable for producing the dry type of alcoholic beverage because of the low reducing sugar content $(0.19 \%)$ and soluble solid $\left(7.2{ }^{\circ} \mathrm{Brix}\right)$. The main organic acids in Yakju were succinic acid, lactic acid, citric acid, malic acid and acetic acid. Further, the succinic acid content in Yakju fermented with La parisienne (black), La parisienne (red) was high (about $1,080 \mathrm{mg} / \mathrm{L}$ ). The main volatile compounds were acetaldehyde, acetic acid and iso-amyl alcohol, and the acetaldehyde and acetic acid contents of the different Yakju samples varied substantially.
\end{abstract}

Key words : yeast, Yakju, quality, commercial, characteristics

\section{서 론}

전통주는 오랜 기간 전승되어 온 술로 우리 민족의 식생 활 풍속이 담겨져 있으며 탁주, 약주, 소주 등을 들 수 있다 (1). 특히 탁·약주는 전분질인 원료 성분이 누룩 중의 젖산 균, 곰팡이 등의 미생물에 의한 효소작용으로 분해되어 생 성되는 당, 아미노산, 유기산 등의 맛 성분과 효모가 내는 알코올 및 휘발성 풍미성분이 색과 품질의 조화를 이루고 있다(2). 위와 같이 탁주의 품질을 좌우하는 요인 중에는 에탄올과 유기산 그리고 향미 성분이 중요하며, 이러한 탁 주의 품질을 변화시키는 요인으로 크게 영향을 미치는 것

*Corresponding author. E-mail : jst@korea.kr

Phone : 82-63-238-3615, Fax : 82-63-238-3843

Received 16 August 2018; Revised 4 September 2018; Accepted 10 September 2018.

Copyright (c) The Korean Society of Food Preservation. All rights reserved.
중의 하나가 발효에 이용되는 효모라고 볼 수 있다. 탁주의 에탄올 생성능은 각 효모마다 차이를 보이는데, 술 제조에 많이 이용되고 있는 Saccharomyces cerevisiae가 에탄올 생 성능이 높고 생존력이 강하다고 하였다(3). 탁주의 품질을 좌우하는 여러 요인 중 효모의 영향을 살펴본 실험 결과에 서도 탁주의 보존성이나 향미에 영향을 주는 가장 중요한 성분인 에탄올 함량은 S. cerevisiae 처리구가 가장 높았고, 알코올 등과 결합하여 에스테르(ester)와 같은 향미 형성 등에 관련되는 성분인 유기산 함량에서는 Saccharomyces rouxii 처리구에서 높은 결과를 보였다(4). 또한, 약주의 맛 에 크게 영향을 미치는 유기산에 있어서, 각각의 효모마다 생성하는 유기산 종류와 그 생성량이 다르다(5)는 것은 효 모의 종류가 약주의 맛에 크게 영향을 미칠 수 있다는 것을 의미한다. 지금까지 효모에 대한 연구는 분리, 동정 및 발효 특성에 대하여 다양하게 진행되어 왔지만(2), 실생활에서 쉽게 분리하고 동정하여 사용하기는 어렵다. 또한, 과실주 에서도 원료의 특성이 품질에 큰 영향을 미치기는 하지만 
사용하는 효모의 종류에 따라서도 품질의 차이를 보일 것이 라는 가정하에 시판 효모를 이용하여 과실주의 발효 및 품질 특성을 비교한 연구가 진행되어 왔다(6-9). 그렇지만 효모가 약주의 품질에 미치는 영향에 대한 연구가 거의 없는 실정이다. 따라서, 본 연구에서는 시중에서 판매되고 있는 다양한 건조효모를 이용하여 약주를 제조한 후 약주의 품질 특성에 미치는 영향을 규명함으로써, 효모에 따라 약 주 발효에서 어떤 특성을 나타내는지 비교 분석하였는바, 그 결과를 보고자 한다.

\section{재료 및 방법}

\section{실험재료}

본 연구는 시판 건조효모의 종류에 따른 약주의 품질특 성을 규명하기 위한 연구로서 효모 이외의 다른 요소에 의해 술에 미치는 영향을 최소화하기 위하여, 약주 제조에 사용된 전분질 원료는 고두밥대신 증자건조미를 이용하였 다. 원료를 당화시키기 위한 발효제는 일반 누룩대신에 당 화효소제로 Eoenzyme(3600sp, Yuhan Eoenzyme, Seoul, Korea)을 사용하였다. 약주 발효에 사용된 건조효모로는 S. I. Lesaffe 사(Marcq-en-Baroeul cedex, France)에서 제조한 La parisienne(red), La parisienne(black) 2종의 $S$. cerevisiae 효모와 Fermivin(DSM Food Specialties, Delft, Netherlands), Lalvin사(Lallemand Inc., Montreal, Canada)의 RC212, K1-V1116, D47, 및 $\mathrm{EC1118(S.} \mathrm{bayanus)} \mathrm{4종으로} \mathrm{총} \mathrm{7종류의}$ 효모를 이용하였으며 효모 종류별 제조회사와 특징은 Table 1에서 자세하게 설명하였다.

\section{약주 담금}

약주는 단담금으로 하였다. 증자건조미 $1 \mathrm{~kg}$, 당화효소제 $10 \mathrm{~g}$, 물 $2 \mathrm{~L}$ 을 가한 후 각각 효모를 $3 \mathrm{~g}$ 접종하여 $20^{\circ} \mathrm{C}$ 에서
10 일 동안 발효하였다. 발효가 끝나면 60 mesh 체로 조여과 하고 $4^{\circ} \mathrm{C}$ 에서 $7,000 \mathrm{rpm}(9,280 \times \mathrm{g})$ 으로 30 분간 원심분리 (Hitachi CR22G III, Hitachi Co., Ltd., Tokyo, Japan)하여상 등액을 약주로 사용하였다.

\section{$\mathrm{pH}$, 총산 및 아미노산도}

약주의 $\mathrm{pH}$, 총산 및 아미노산도는 국세청 주류분석 규정 을 따랐다(10). $\mathrm{pH}$ 는 $\mathrm{pH}$ meter(Orion 3 Star Benchtop pH meter, Thermo Fisher Scientific Inc., Waltham, MA, USA)로 측정하였으며, 총산은 시료 $10 \mathrm{~mL}$ 를 취하여 $100 \mathrm{~mL}$ 용 삼각 플라스크에 넣고 $0.1 \mathrm{~N}$ 수산화나트륨 $(\mathrm{NaOH}$, Yakuri pure chemical Co., Ltd., Kyoto, Japan) 용액으로 $\mathrm{pH}$ 8.2가 될 때까지 적정하여 그 값을 초산(acetic acid)으로 환산하여 나타내었다. 국세청 주류분석 규정을 따라(10) 아미노산도 는 시료 $10 \mathrm{~mL}$ 를 $100 \mathrm{~mL}$ 삼각플라스크에 취한 다음, 페놀 프탈레인 지시약 2-3방울을 가하여 $0.1 \mathrm{~N} \mathrm{NaOH}$ 용액으로 엷은 분홍색이 나올 때까지 적정하였다. 여기에 중성포르 말린 용액(Yakuri pure chemical Co., Ltd.) $5 \mathrm{~mL}$ 를 넣어 원래의 색이 나오게 한 후 다시 $0.1 \mathrm{~N} \mathrm{NaOH}$ 용액으로 엷은 분홍색이 나올 때까지 적정하여 소비된 용액의 양 $(\mathrm{mL})$ 으로 표시하였다.

\section{가용성 고형분 $\left({ }^{\circ} \mathrm{Brix}\right)$ 및 환원당 함량}

가용성 고형분 $\left({ }^{\circ} \mathrm{Brix}\right)$ 함량은 디지털 굴절계(PR-201, Atago Co., Tokyo, Japan)를 사용하여 측정하였으며, 환원당 은 Dinitrosalicylic acid법을 변형하여 분석하였다(11). 즉, 희석된 여과액을 $1 \mathrm{~mL}$ 에 DNS시약 $3 \mathrm{~mL}$ 을 가하여 water bath(B-490, BUCHI, Flawil, Switzerland)에서 5분간 가열시 킨 후 급냉하고 여기에 증류수 $5 \mathrm{~mL}$ 을 첨가하여 UV-visible spectrophotometer(JP/U-2000 spectrophotometer, Hitachi Co., Ltd.)를 이용하여 $550 \mathrm{~nm}$ 에서 흡광도를 측정하였다. 이때 당 정량은 glucose를 표준물질로 사용하여 상기의 방 법으로 작성한 표준곡선으로부터 환산하였다.

Table 1. Commercial yeasts used in this study

\begin{tabular}{|c|c|c|c|c|}
\hline \multirow{2}{*}{ Brand name } & \multirow{2}{*}{ Manufacturer } & \multirow{2}{*}{ Species } & \multicolumn{2}{|c|}{ (haracteristics ${ }^{4}$} \\
\hline & & & Optimum temp. range $\left({ }^{\circ} \mathrm{C}\right)$ & Alcohol tolerance $(\%)$ \\
\hline La parisienne (red) & S. I. Lesaffre ${ }^{1)}$ & S. cerevisiae & $15-35$ & - \\
\hline La parisienne (black) & S. I. Lesaffre & $S$ cerevisiae & $15-36$ & - \\
\hline Fermivin & $\mathrm{DSM}^{2)}$ & S. cerevisiae & $15-37$ & 14 \\
\hline $\mathrm{RC} 212$ & Lalvin $^{3)}$ & S. cerevisiae & $15-30$ & $12-14$ \\
\hline K1-V1116 & Lalvin & $S$. cerevisiae & $15-31$ & 18 \\
\hline D47 & Lalvin & S. cerevisiae & $10-30$ & 14 \\
\hline EC1118 & Lalvin & S. bayanus & $7-35$ & 18 \\
\hline
\end{tabular}

${ }^{1)}$ S. I. Lesaffre, Marcq-en-Baroeul cedex, France.

${ }^{2}$ DSM Food Specialties, Delft, The Netherlands.

${ }^{3)}$ Lallemand Inc., Montreal, Canada.

${ }^{4}$ Information from commercial wine yeast maker. 


\section{알코올 함량 및 휘발산 함량 측정}

알코올 함량은 시료 $100 \mathrm{~mL}$ 를 증류 및 냉각 장치에 연결 하고 가열하여 증류액을 약 $80 \mathrm{~mL}$ 이상 받고 $100 \mathrm{~mL}$ 까지 증류수로 정용하였다. 증류액을 잘 혼합한 다음 주정계 (Dongmyeong, Seoul, Korea)를 사용하여 눈금을 읽고 주정 분 온도 환산표로서 $15^{\circ} \mathrm{C}$ 로 보정하여 알코올 농도 $(\%, \mathrm{v} / \mathrm{v})$ 로 나타내었다. 또는 증류액을 $15^{\circ} \mathrm{C}$ 로 조정하여 알코올 분 석기(AL-3, Riken Keiki, Tokyo, Japan)를 이용하여 측정하 였다. 약주의 휘발산 함량은 알코올 분석용 증류액 $30 \mathrm{~mL}$ 를 취하여 삼각플라스크에 넣고 $0.01 \mathrm{~N} \mathrm{NaOH}$ 로 $\mathrm{pH}$ 8.2가 될 때까지 적정하여 소비된 $0.01 \mathrm{~N} \mathrm{NaOH}$ 를 초산(acetic acid) 으로 환산하여 표시하였다.

\section{유기산 함량 측정}

유기산 분석에 사용한 모든 시료는 분석 전에 HLB-plus Sep-pak cartridge(Waters Corporation, Milford, MA, USA)를 통과시킨 후 $0.45 \mu \mathrm{m}$ membrane filter로 여과하였다. 각 시료 의 유기산은 HPLC(LC-20series, Shimadzu Co., Tokyo, Japan)를 이용하여 분석하였다. 분석용 column은 Aminex HPX-87H(300×7.8 mm, Bio-Rad Co., Hercules, CA, USA)을 사용하였으며, $4 \mathrm{mM}$ sulfuric acid를 이동상으로 하여 $35^{\circ} \mathrm{C}$ 에서 $0.6 \mathrm{~mL} / \mathrm{min}$ 의 유속으로 분리하였다. 시료 주입량은 $20 \mu \mathrm{L}$ 이었으며 UV 검출기를 이용하여 $210 \mathrm{~nm}$ 에서 검출하 였다.

\section{휘발성 향기성분}

향기성분 분석에 사용한 기기는 GC2010(Shimadzu Co.) 이었으며, column은 HP-INNOWAX(60 m×0.25 mm×0.25 $\mu \mathrm{m}$, Agilent, CA, USA)을 사용하였다(12). 분석조건은 column 온도 $45^{\circ} \mathrm{C}$ 에서 5 분간 머무름, $100^{\circ} \mathrm{C}$ 까지 분당 $5^{\circ} \mathrm{C}$ 로 승온, 5 분간 머무름, 분당 $10^{\circ} \mathrm{C}$ 로 승온, $200^{\circ} \mathrm{C}$ 에서 5 분간 머무름, 분당 $5^{\circ} \mathrm{C}$ 로 승온, 최종 $250^{\circ} \mathrm{C}$ 까지 승온한 후 10 분간 머무름 시간을 주었다. Carrier gas는 nitrogen gas을 2 $\mathrm{mL} / \mathrm{min}$ 속도로 흘려주었으며, 샘플은 injection 온도 $250^{\circ} \mathrm{C}$
에서 주입되도록 하였으며 split ratio 100:1, detecter는 FID 로 $250^{\circ} \mathrm{C}$ 에서 검출하였다.

\section{통계분석}

모든 데이터는 3회 반복 측정하였으며, 평균표준편차 로 표시하였다. 통계분석은 SPSS 프로그램 12.0 버전을 이 용하여 처리구간의 유의적인 차이를 알아보기 위해 일원분 산분석(One-way ANOVA)을 실시하였다. 시료간 유의적인 차이가 있을 경우, $a=0.05$ 수준에서 Duncan의 다중범위 검정을 실시하였다.

\section{결과 및 고찰}

\section{$\mathrm{pH}$ 및 총산}

발효 완료 후 각 효모별 $\mathrm{pH}$ 및 총산은 Table 2 와 같다. 발효 완료 후 $\mathrm{pH}$ 는 4.07-4.53 이었으며, 효모 $\mathrm{La}$ parisienne (red), La parisienne(black), K1-V1116은 높게 나타난 반면, EC1118, Fermivin, D47, RC 212는 비교적 낮은 $\mathrm{pH}$ 를 보였 다. 이러한 결과는 발효 중에 효모가 생산하는 유기산의 종류나 생성량에 있어서 서로 차이가 있기 때문인 것으로 생각된다. Woo 등(13)에 따르면 약주나 탁주 제조에서 산 함량은 주로 사용하는 누룩과 발효온도에 영향을 받는다고 하였는데, 본 연구에서는 누룩의 미생물적인 요소를 배제 시키기 위하여 당화효소제를 이용하였고 일정한 온도에서 발효시켰기 때문에 발효액의 총산 함량은 효모 유래의 차이 라고 할 수 있다. 총산은 $\mathrm{pH}$ 의 값이 낮을수록 높은 경향을 보였는데, La parisienne(red)와 La parisienne(black) 처리 약 주는 적은 반면 $\mathrm{EC1118}$ 효모로 발효시킨 약주는 비교적 많은 총산을 보여, $\mathrm{EC} 1118$ 효모가 막걸리 제조에 있어서 유기산 함량을 높여 상큼한 맛을 높이는데 이용될 수 있을 것으로 생각된다.

Table 3의 유기산 분석 결과와 비교해볼 때, 총산함량이 높은 EC1118은 젖산(lactic acid)을 많이 생성하였으며, 상

Table 2. Qualities of Yakju fermented with different commercial yeasts

\begin{tabular}{|c|c|c|c|c|c|c|c|}
\hline & $\mathrm{pH}$ & $\begin{array}{l}\text { Total acid } \\
(\%, \mathrm{w} / \mathrm{v})\end{array}$ & Amino acidity & Soluble solid ( ${ }^{\circ}$ Brix $)$ & $\begin{array}{l}\text { Reducing sugar } \\
(\%, \mathrm{w} / \mathrm{v})\end{array}$ & $\begin{array}{l}\text { Alcohol } \\
(\%, \mathrm{v} / \mathrm{v})\end{array}$ & $\begin{array}{l}\text { Volatile acid } \\
\text { (ppm) }\end{array}$ \\
\hline La parisienne (red) & $4.53 \pm 0.07^{1) \mathrm{a} 2}$ & $0.26 \pm 0.02^{c}$ & $5.34 \pm 0.34^{\mathrm{a}}$ & $7.30 \pm 0.25^{\mathrm{ab}}$ & $0.23 \pm 0.04$ & $12.03 \pm 0.29^{\mathrm{ab}}$ & $60.27 \pm 15.70^{c}$ \\
\hline La parisienne (black) & $4.49 \pm 0.06^{\mathrm{a}}$ & $0.32 \pm 0.04^{b}$ & $5.55 \pm 0.22^{\mathrm{a}}$ & $7.53 \pm 0.21^{\mathrm{a}}$ & $0.21 \pm 0.03$ & $11.83 \pm 0.6^{\mathrm{ab}}$ & $80.20 \pm 31.99^{b c}$ \\
\hline Fermivin & $4.11 \pm 0.02^{c}$ & $0.35 \pm 0.02^{\mathrm{ab}}$ & $2.49 \pm 0.28^{c}$ & $6.87 \pm 0.21^{\mathrm{c}}$ & $0.20 \pm 0.01$ & $10.13 \pm 0.42^{c}$ & $101.60 \pm 18.11^{\mathrm{abc}}$ \\
\hline $\mathrm{RC} 212$ & $4.16 \pm 0.02^{b c}$ & $0.35 \pm 0.00^{\mathrm{ab}}$ & $3.91 \pm 0.13^{\mathrm{b}}$ & $7.33 \pm 0.10^{\mathrm{ab}}$ & $0.23 \pm 0.01$ & $12.37 \pm 0.31^{\mathrm{a}}$ & $82.93 \pm 25.36^{\mathrm{bc}}$ \\
\hline K1-V1116 & $4.36 \pm 0.02^{\mathrm{ab}}$ & $0.32 \pm 0.01^{b}$ & $5.59 \pm 0.42^{\mathrm{a}}$ & $7.07 \pm 0.06^{b c}$ & $0.21 \pm 0.01$ & $10.67 \pm 0.95^{b c}$ & $73.93 \pm 19.21^{b c}$ \\
\hline D47 & $4.14 \pm 0.11^{b c}$ & $0.33 \pm 0.02^{b}$ & $4.24 \pm 0.29^{b}$ & $7.40 \pm 0.10^{\mathrm{ab}}$ & $0.22 \pm 0.04$ & $11.20 \pm 1.40^{\mathrm{abc}}$ & $107.60 \pm 9.40^{\mathrm{ab}}$ \\
\hline EC1118 & $4.07 \pm 0.08^{c}$ & $0.40 \pm 0.04^{a}$ & $4.11 \pm 0.20^{b}$ & $7.17 \pm 0.21^{\mathrm{bc}}$ & $0.19 \pm 0.02$ & $12.13 \pm 0.35^{\mathrm{a}}$ & $130.47 \pm 35.28^{\mathrm{a}}$ \\
\hline
\end{tabular}

${ }^{1)}$ The values are expressed as mean $\pm \mathrm{SD}(\mathrm{n}=3)$.

2)a-c Means with a different superscript within a column is significantly different at $\mathrm{p}<0.05$ by Duncan's multiple range test. 
Table 3. Organic acid content of Yakju fermented with different commercial yeasts

\begin{tabular}{cccccc}
\hline & \multicolumn{5}{c}{ Organic acids (mg/L) } \\
\cline { 2 - 6 } & Citric acid & Malic acid & Succinic acid & Lactic acid & Acetic acid \\
\hline La parisienne (red) & $223.70 \pm 54.41^{1 \text { b2) }}$ & $585.29 \pm 62.96^{\mathrm{a}}$ & $1,083.81 \pm 97.40^{\mathrm{b}}$ & $178.46 \pm 309.11^{\mathrm{c}}$ & $252.69 \pm 39.03$ \\
La parisienne (black) & $217.91 \pm 105.03^{\mathrm{b}}$ & $116.50 \pm 19.72^{\mathrm{c}}$ & $1,079.47 \pm 116.67^{\mathrm{b}}$ & $0.00 \pm 0.00^{\mathrm{c}}$ & $256.16 \pm 56.99$ \\
Fermivin & $364.23 \pm 14.02^{\mathrm{a}}$ & $509.99 \pm 53.99^{\mathrm{a}}$ & $1,331.73 \pm 105.87^{\mathrm{a}}$ & $7,928.55 \pm 1290.39^{\mathrm{a}}$ & $327.97 \pm 31.31$ \\
RC212 & $404.31 \pm 31.41^{\mathrm{a}}$ & $339.94 \pm 92.99^{\mathrm{b}}$ & $1,080.19 \pm 115.51^{\mathrm{b}}$ & $4,438.59 \pm 1973.41^{\mathrm{ab}}$ & $298.00 \pm 33.13$ \\
K1-V1116 & $380.32 \pm 20.99^{\mathrm{a}}$ & $168.70 \pm 33.43^{\mathrm{c}}$ & $1,208.20 \pm 18.51^{\mathrm{ab}}$ & $1,463.47 \pm 833.15^{\mathrm{bc}}$ & $347.33 \pm 29.99$ \\
D47 & $369.25 \pm 73.56^{\mathrm{a}}$ & $333.50 \pm 126.87^{\mathrm{b}}$ & $1,158.03 \pm 72.24^{\mathrm{b}}$ & $3,904.05 \pm 4416.02^{\mathrm{bc}}$ & $388.26 \pm 63.33$ \\
EC1118 & $349.38 \pm 60.14^{\mathrm{a}}$ & $247.56 \pm 75.36^{\mathrm{bc}}$ & $1,125.96 \pm 65.21^{\mathrm{b}}$ & $1,489.46 \pm 1956.49^{\mathrm{bc}}$ & $339.10 \pm 86.40$ \\
\hline
\end{tabular}

${ }^{1}$ The values are expressed as mean $\pm \mathrm{SD}(\mathrm{n}=3)$.

${ }^{2) a-c}$ Means with a different superscript within a column is significantly different at $\mathrm{p}<0.05$ by Duncan's multiple range test.

대적으로 총산 함량이 적은 La parisienne(red)는 젖산 함량 이 적었다. 즉 발효 중 생성되는 젖산의 함량이 발효액의 총산에 큰 영향을 미치며 또한 $\mathrm{pH}$ 에도 영향을 미친다는 것을 알 수 있었다.

\section{가용성 고형분 $\left({ }^{\circ} \mathrm{Brix}\right)$ 및 환원당 함량}

가용성 고형분과 환원당 함량은 Table 2 와 같다. 가용성 고형분 함량은 발효완료 후 6.8-7.5 ${ }^{\circ} \mathrm{Brix}$ 로 La parisienne (black)이 가장 높았고 Fermivin 처리구에서 가장 낮았다. 환원당의 함량은 발효 완료 후 $0.19-0.22 \%$ 로 효모의 종류에 따라 큰 차이가 없었으며 본 실험에 사용한 효모는 당을 약 $0.2 \%$ 까지 분해하는 것으로 나타났다. 알코올 농도나 환원당 함량에는 큰 차이가 없는데도 불구하고 가용성 고형 분에 차이가 있다는 것은 알코올이나 환원당 이외 가용성 고형분 함량에 차이가 있다는 것을 의미한다. Seo 등(14)의 연구에 의하면 가용성고형분 함량이 높을수록 강한 단맛을 느낀다고 보고한 바 있다. 본 실험에서 단맛에 대한 관능적 특성결과 La parisienne(black)과 Fermivin의 가용성고형물 함량이 $0.7{ }^{\circ} \mathrm{Brix}$ 차이가 있음에도 불구하고 단맛에 대한 기호성 평가에서는 유의적인 차이는 없었다(data not shown).

\section{알코올 함량}

효모 종류를 달리한 약주 발효 완료 후 알코올 함량은 Table 2와 같이 $10.1-12.1 \%$ 정도로 처리 간에 차이가 있는 것을 확인하였다. Fermivin, K1-V1116, D47은 10.1-11.2\% 로 다른 효모에 비해 비교적 낮은 알코올 함량을 보인 반면 $\mathrm{RC} 212$ 과 $\mathrm{EC} 1118$ 효모 처리는 높은 특징을 보였다. Shin 등(5)의 실험 결과에서도 효모마다 알코올 생성능이 다름을 볼 수 있었고, 본 실험에서도 효모 종류에 따라 약주의 알코 올 농도에 차이가 있다는 결과를 볼 수 있었다. 발효 완료 후 총당과 환원당 함량 대비 알코올 함량을 비교해 보았을 때, $\mathrm{EC} 1118$ 이 환원당과 총당이 각각 $0.19 \%, 7.2{ }^{\circ} \mathrm{Brix}$ 로 평균적으로 적은 함유량을 보인 데 반해 알코올 함량은
$12.1 \%$ 로 다른 효모보다 비교적 높은 것으로 보아 알코올 발효효율이 좋은 것으로 판단된다. 반대로 D47은 발효완료 후 환원당 $0.22 \%$, 총당 $7.4{ }^{\circ} \mathrm{Brix}$ 대비 알코올 함량 $11.2 \%$ 를 보여 다른 효모들에 비해 알코올 발효효율이 떨어지는 것으 로 보인다. Lee 등(4)의 실험 결과에서도 주모 제조용 효모 종류를 달리하여 담금 한 탁주 술덧의 발효과정 중 알코올 함량과 성분에 차이를 나타냈고, Jeong 등(15)의 결과를 본 실험 결과와 비교해 볼 때도, $\mathrm{EC} 1118$ 이 다른 효모에 비해 알코올 발효능력이 높다는 결과와 비슷한 경향을 나타 내었다. 따라서 본 실험에서 알코올 발효능력이 우수했던 $\mathrm{EC} 1118$ 효모는 주류 판매에 있어 발효 완료 후 규정된 알코올 농도로 맞추어 출시하는 경우, 발효 효율이 좋기 때문에 원료대비 발효주의 수율이 높을 것으로 예상된다.

\section{아미노산도 및 휘발산 함량}

발효 완료 후 아미노산도는 Table 2에서 보여주는 바와 같다. 아미노산도는 2.49-5.59로 큰 차이를 보였다. K1-V1116, La parisienne(black), La parisienne(red)는 아미 노산도가 5.59-5.34로 비교적 높았으며, Fermivin은 2.49로 낮은 수치를 보였다. 단백질 그 자체는 맛이 없으나 그 분해 생산물인 아미노산은 각각 특유한 맛을 나타낸다. L-leucine, L-isoleucine, L-phenylalanine, L-tryptophan 등 소 수성 아미노산은 쓴맛을 갖고, glycine, L-alanine, $\mathrm{D}, \mathrm{L}$-serine, L-hydroxyproline, L-lysine 등은 단맛을 가진다 고 알려져 있다(16) $\mathrm{Kim}$ 등(17)은 아미노산도가 1.5정도일 때 적당한 맛을 내어 술맛을 상승시키는 효과가 있다고 하였다. 본 연구에서는 아미노산도가 효모의 종류에 따라 2.49-5.59로 비교적 넓은 범위를 보임을 알 수 있었다. 이러 한 정보는 막걸리나 약주 제조에 있어서 유용한 자료로 활용할 수 있는데, 발효완료 후 일반적으로 일정비율 물로 희석하는 막걸리는 La parisinne(red), La parisinne(black), $\mathrm{K} 1-\mathrm{V} 1116$ 과 같이 아미노산도가 높은 효모가 적합할 것으 로 생각되며, 약주에서는 깔끔한 맛을 주기 위해서는 Fermivin과 같이 아미노산도가 낮은 효모가 유용하게 사용 
될 수 있을 것으로 생각된다.

발효 완료 후 휘발산 함량을 측정해본 결과, 60.3-130.5 $\mathrm{ppm}$ 정도의 함량을 보였는데, EC1118은 $130.5 \mathrm{ppm}$ 으로 비교적 높은 수치를 보였고, La parisienne(red)와 K1-V1116 은 $60.3 \mathrm{ppm}$ 과 $73.9 \mathrm{ppm}$ 으로 비교적 낮게 나왔다. 약주에 있어서 휘발산은 주로 초산(acetic acid) 등으로 휘발산이 높다는 것은 그 만큼 발효 중에 이들 휘발산을 생성하는 미생물에 오염이 되었다는 것을 의미하며(18), 발효주에는 Acetobacter aceti나 Gluconobacter oxydans 등의 초산 생성 균이 발견되며, 이들 세균이 발효주 표면에 생기면 반투명 의 점착성이 있는 막을 형성하여 발효주가 혼탁해진다(19). 따라서 휘발산이 많은 약주는 기호성에 있어서도 바람직하 지 않다. 본 연구에서는 약 $60-130 \mathrm{ppm}$ 정도의 휘발산이 검출되어 일반적으로 약주에 함유되어 있는 50-100 ppm과 큰 차이를 나타내지 않아 제품의 품질에 영향을 미치지 않은 것으로 판단된다(20).

\section{유기산 함량}

약주 발효 완료 후 유기산의 종류를 $\mathrm{HPLC}$ 를 이용해 분석 한 결과는 Table 3 에서 보는 바와 같다. 유기산 종류별 함량 은 각 효모마다 다르게 나타났고, 공통적으로 비교적 많은 양을 함유한 유기산으로는 호박산(succinic acid) 이었으며, $1,331.73 \mathrm{mg} / \mathrm{L}$ 로 Fermivin이 가장 많았고 1,079.47-1,331.73 $\mathrm{mg} / \mathrm{L}$ 로 함유량 차이를 나타냈다. 구연산(citric acid)은 $\mathrm{RC} 212$ 효모가 $404.31 \mathrm{mg} / \mathrm{L}$ 로 가장 많았고, 사과산(malic acid)은 La parisienne(red) 가 $585.29 \mathrm{mg} / \mathrm{L}$ 로 가장 많이 함유 한 것으로 나타났다. 다음으로 Fermivin 효모는 젓산(lactic acid)과 호박산을 많이 함유한 것으로 나타났는데, 특히 젖 산이 다른 효모에 비해 월등히 높게 나왔다. 주로 약주에서 의 젖산은 발효제로 누룩을 사용 시 초기에 생성되는 lactic acid bacteria에 의하여 생성되지만, 본 실험에서는 누룩을 사용하지 않았기 때문에 Fermivin은 본 실험에 사용된 다른
효모들에 비해 젖산을 비교적 많이 생성하는 것으로 판단된 다. Hwang 등(21)의 결과에서도 원료는 다르지만 Fermivin 의 유기산 분석 결과 젖산의 함량이 여러 효모군 중에 비교 적 높은 수치를 나타내었고 Fermivin에서 검출된 유기산 종류 중에 젖산의 함량이 가장 높아, 본 실험 결과와 어느 정도 부합하는 면이 있어 이 효모가 생성하는 유기산 중 주요 유기산은 젖산인 것으로 보인다.

반대로 La parisienne(red)와 La parisienne(black) 효모는 젖산이 비교적 적은 양이 함유되어 있거나, 전혀 함유되지 않고 호박산이 다른 유기산에 비해 비교적 많은 양이 함유 된 것으로 보았을 때 La parisienne(red), La parisienne(black) 효모로 제조한 약주에서 측정되는 산도는 주로 호박산에 의한 것으로 보인다. 특히, 호박산은 신맛뿐만 아니라 감칠 맛이 높기 때문에(22) 호박산이 많이 함유된 La parisienne (red), La parisienne(black) 효모로 발효하여 희석 비율이 높은 막걸리 제조에 적합할 것으로 사료된다. 마지막으로 막걸리 풍미에 좋지 않은 영향을 미치는 acetic acid는 다른 유기산에 비해 많은 양을 보이진 않았지만 비교적 D47 효모 에서 $388.26 \mathrm{mg} / \mathrm{L}$ 로 높은 함량을 나타냈다.

약.탁주의 주요 유기산으로 젖산, 호박산, 초산으로 보고 되어 있으며(23), 약주나 막걸리의 유기산 함량은 사용하는 발효제의 종류에 따라 크게 영향을 미치는 것으로 알려져 있다(4). 본 실험은 막걸리용 입국을 사용하지 않았는데도 전 실험들과 같이 주된 유기산의 종류가 비슷한 것으로 보아, 효모에 의해서도 다양한 유기산이 생성됨을 알 수 있었으며, 효모의 종류에 따라 생성되는 주된 유기산 종류 가 다르다는 것을 확인하였다. 이러한 정보들은 약주나 막 걸리 양조에 있어서 효모의 선택이 맛에 크게 영향을 미칠 수 있다는 것을 나타낸다.

\section{휘발성 향기성분 함량}

발효 완료 후 효모별 향기 성분 분석 결과는 Table 4

Table 4. Volatile compounds of Yakju fermented with different commercial yeasts

\begin{tabular}{|c|c|c|c|c|c|c|c|c|}
\hline $\begin{array}{l}\text { Volatile compounds } \\
\qquad(\mathrm{ppm})\end{array}$ & $\begin{array}{l}\text { La parisienne } \\
\text { (red) }\end{array}$ & $\begin{array}{l}\text { La parisienne } \\
\text { (black) }\end{array}$ & Fermivin & $\mathrm{RC} 212$ & K1-V1116 & D47 & $\mathrm{EC} 1118$ & $\mathrm{p}$ \\
\hline Acetaldehyde & $313.18 \pm 20.60^{1) \mathrm{d} d 2}$ & $481.16 \pm 240.65^{b c}$ & $0.00 \pm 0.00^{\mathrm{d}}$ & $0.00 \pm 0.00^{\mathrm{d}}$ & $971.43 \pm 0.00^{\mathrm{a}}$ & $720.46 \pm 457.77^{\mathrm{ab}}$ & $599.03 \pm 154.27^{\mathrm{abc}}$ & 0.000 \\
\hline $\mathrm{EtOH}(\%)$ & $11.79 \pm 0.30$ & $11.69 \pm 0.60$ & $11.72 \pm 0.14$ & $11.40 \pm 0.07$ & $11.20 \pm 0.43$ & $11.17 \pm 0.62$ & $11.61 \pm 0.83$ & 0.599 \\
\hline Iso-butanol & $86.50 \pm 11.27$ & $88.6 \pm 10.33$ & $83.10 \pm 3.97$ & $90.61 \pm 28.88$ & $103.00 \pm 8.78$ & $117.37 \pm 56.70$ & $95.25 \pm 33.09$ & 0.772 \\
\hline Iso-amylalcohol & $294.63 \pm 18.96^{\mathrm{a}}$ & $298.02 \pm 17.55^{\mathrm{a}}$ & $335.18 \pm 3.25^{\mathrm{a}}$ & $329.12 \pm 36.22^{\mathrm{a}}$ & $320.29 \pm 14.38^{\mathrm{a}}$ & $234.43 \pm 74.80^{b}$ & $305.45 \pm 11.36^{\mathrm{a}}$ & 0.042 \\
\hline n-Hexanol & $12.24 \pm 0.00^{\mathrm{abc}}$ & $9.10 \pm 0.00^{\mathrm{bc}}$ & $0.00 \pm 0.00 \mathrm{c}$ & $9.25 \pm 0.00^{\mathrm{bc}}$ & $12.84 \pm 0.00^{\mathrm{abc}}$ & $37.75 \pm 35.69^{\mathrm{a}}$ & $34.31 \pm 7.31^{\mathrm{ab}}$ & 0.038 \\
\hline Acetic acid & $239.75 \pm 116.85$ & $429.61 \pm 71.05$ & $592.05 \pm 7.95$ & $547.06 \pm 14.10$ & $592.88 \pm 48.71$ & $1,087.01 \pm 859.46$ & $610.04 \pm 96.97$ & 0.169 \\
\hline Linalool & $96.35 \pm 29.29^{b}$ & $165.80 \pm 25.15^{\mathrm{a}}$ & $143.81 \pm 23.45^{\mathrm{a}}$ & $144.27 \pm 2.65^{\mathrm{a}}$ & $157.15 \pm 7.63^{\mathrm{a}}$ & $158.95 \pm 23.39^{\mathrm{a}}$ & $142.22 \pm 27.31^{\mathrm{a}}$ & 0.033 \\
\hline Ethyl caprate & $19.18 \pm 5.75^{\mathrm{c}}$ & $26.33 \pm 1.71^{b}$ & $33.52 \pm 1.50^{\mathrm{a}}$ & $19.68 \pm 1.68^{\mathrm{c}}$ & $25.80 \pm 1.39^{b}$ & $21.65 \pm 2.08^{c}$ & $30.40 \pm 1.16^{\mathrm{a}}$ & 0.000 \\
\hline 2-Phenylethanol & $34.07 \pm 9.22^{c}$ & $52.87 \pm 3.89^{b}$ & $67.20 \pm 3.14^{\mathrm{a}}$ & $67.15 \pm 2.81^{\mathrm{a}}$ & $62.38 \pm 1.88^{\mathrm{ab}}$ & $58.46 \pm 8.66^{\mathrm{ab}}$ & $56.79 \pm 2.68^{\mathrm{b}}$ & 0.000 \\
\hline
\end{tabular}

${ }^{1)}$ The values are expressed as mean \pm SD $(n=3)$.

${ }^{2) a-d}$ Means with a different superscript within a row is significantly different at $p<0.05$ by Duncan's multiple range test. 
와 같다. 효모의 종류를 달리하여 제조한 약주의 향기성분 은 약주마다 서로 다르게 향기성분이 검출되었다. $\operatorname{Kim}(24)$ 의 보고에 의하면, 일반적으로 약주에 들어 있는 주요 향미 성분들은 아세트알데히드, 에틸아세테이트, 에탄올, 프로 필알코올, 이소부틸알코올, 이소아밀 알코올, 초산이라 하 였고, 본 실험 결과에서도 위와 같이 동일하게 성분들이 검출되었다. 효모의 종류를 달리하여 제조한 약주의 에탄 올 함량이 대부분을 차지했으며, 에탄올 함량을 제외하고, 다음으로 많은 함량을 차지하는 약주의 향기성분으로는 아세트알데히드, 초산, 이소아밀알코올 등으로 이루었다. 아세트알데히드는 Fermivin과 RC212를 제외한 나머지 약 주에서의 함유량은 313.2-971.4 ppm으로 비교적 큰 차이를 나타냈고, 아세트산은 모든 효모에서 나타내고 함유량은 239.8-1,087.0 ppm으로 큰 차이를 나타냈다. 이소부탄올은 83.1-117.4 ppm의 양이 검출되었고 Fermivin이 $83.1 \mathrm{ppm}$, $\mathrm{D} 47$ 이 $117.4 \mathrm{ppm}$ 로 최저와 최고 함량의 차이가 비교적 큰 차이를 보이지 않았다. 이소아밀알코올은 234.4-335.2 $\mathrm{ppm}$ 이 검출되었다. 이소아밀알코올은 $80-350 \mathrm{ppm}$ 사이에 서 쾌감을 주는 범위이고, 이소부탄올은 $220 \mathrm{ppm}$ 이 초과하 면 불쾌감을 준다는 보고(25)를 비춰볼 때 각각의 효모로 제조된 약주가 불쾌감을 주는 범위에 속하지 않는다는 것을 알 수 있었다.

\section{요 약}

본 연구는 시판되고 있는 효모의 종류에 따라 약주의 품질 특성에 미치는 영향을 보고자 하였다. 발효 완료 후 총산은 $0.26 \%$ 에서 $0.40 \%$ 범위였으며, 가장 낮은 것은 $\mathrm{La}$ parisinne(red)로 발효시킨 약주였고 가장 높은 것은 EC1118 효모로 발효시킨 약주였다. 발효에 사용한 효모의 종류에 따라 약주의 아미노산도는 2.49-5.59 범위로 큰 차이를 나타 냈는데, K1-V1116, La parisienne(black), La parisienne(red) 로 발효시킨 약주는 아미노산도가 각각 $5.59,5.55,5.34$ 로 비교적 높았다. 반면에 Fermivin으로 발효시킨 약주는 2.49 로 다른 효모로 빚은 약주에 비해 낮은 수치를 보였다. $\mathrm{EC} 1118$ 효모로 양조한 약주의 경우, 발효 완료 후 환원당과 가용성고형물이 $0.19 \%$ 및 $7.17^{\circ} \mathrm{Brix}$ 로 낮아, 잔당이 적은 드라이타입의 약주제조에 적합할 것으로 판단된다. 본 연 구에서 제조한 약주의 주요 유기산은 호박산과 젖산이었으 며, 특히 La parisienne(black), La parisienne(red)로 발효시킨 약주에서 신맛보다는 감칠맛을 내는 호박산이 많이 함유되 었다. 이것으로 아미노산도가 높고 감칠맛을 내는 호박산 을 많이 생성하며 고온에서도 발효가 가능한 La parisienne 이 탁-약주 발효에 사용하여도 무방할 것으로 사료된다. 또한, 주요 휘발성 성분은 아세트알데히드와 초산 그리고 이소아밀알코올이었으며, 그중에 아세트알데히드와 초산
함량은 본 연구에 사용한 효모의 종류에 따라 크게 차이가 있었다.

\section{감사의 글}

본 연구는 국립농업과학원 농업과학기술 연구개발사업 (과제번호: PJ012594)의 지원에 의해 이루어진 것이며, 연 구비 지원에 감사드립니다.

\section{References}

1. Kim JY, Park GS (2014) Analysis of consumers' present use and future demand of traditional Korean liquors. Korean J Food Cookery Sci, 30, 41-50

2. Kim HR, Kwon YH, Jo SJ, Kim JH, Ahn BH (2009) Characterization and volatile flavor components in glutinous prepared with different yeasts of Nuruks. Korean J Food Sci Technol, 41, 296-301

3. Kang TY, Oh GH, Kim K (2000) Isolation and identification of yeast strains producing high concentration of ethanol with high viability. Korean J Appl Microbiol biotechnol, 28, 309-315

4. Lee HS, Park CS, Choi JY (2010) Quality characteristics of the mashes of Takju prepared using different yeasts. Korean J Food Sci Technol, 42, 56-62

5. Shin KR, Kim BC, Yang JY, Kim YD (1999) Characterization of Yakju prepared with yeasts from fruits: 2. Quality characteristics of Yakju during fermentation. J Korean Soc Food Sci Nutr, 28, 801-804

6. Lee HY, Lee HY, Kwon HJ, Park JS, Ahn MS, Jeong ST, Yi JH (2016) Comparison of quality characteristics of 'cheonghyang' wine fermented with different commercial yeasts. J East Asian Soc Diet Life, 26, 543-549

7. Park HS (2010) Characteristics of peach wine with different commercial yeast strains. J East Asian Soc Diet Life, 20, 531-535

8. Lee YJ, Kim JC, Hwang KT, Kim DH, Jung CM (2013) Quality characteristics of black raspberry wine fermented with different yeasts. J Korean Soc Food Sci Nutr, 42, 784-791

9. Lee SH, Park HK, Kim MH (2010) Physicochemical characteristics and sensory properties of Omija wines fermented by active dry yeast strains. Korean J Food Sci Technol, 42, 739-742 
10. National Tax Service Liquors License Aid. Analysis provisions of alcoholic beverages. http://www.i.nts.go.kr (accessed May 2018)

11. Park JH, Bae SM, Yook C, Kim JS (2004) Fermentation characteristics of Takju prepared with old rice. Korean J Food Sci Technol, 36, 609-615

12. Choi HS, Kim EG, Kang JE, Yeo SH, Jeong ST, Kim CW (2015) Effect of organic acids addition to fermentation on the brewing characteristics of Soju distilled from rice. Korean J Food Sci Technol, 47, 579-585

13. Woo SM, Shin JS, Seong JH, Yeo SH, Choi JH, Kim TY, Jeong YJ (2010) Quality characteristics of brown rice Takju by different Nuruks. J Korean Soc Food Sci Nutr, 39, 301-307

14. Seo JS, Lee JS, Byun GI, Kwak EJ (2008) Quality characteristics of Yakju fermented with wild grape and 4 kinds of cereals. J Korean Soc Food Sci Nutr, 37, $1472-1478$

15. Jeong ST, Nami GY (2001) Species identification and fermentation characteristics of commercial wine yeasts. J ASEV Jpn, 12, 10-20

16. Chae SG, Kim SH, Sin DH, Oh HG, Lee SG, Jang MH, Choi W (2000) Food Chemistry. Hyoil books, Seoul, Korea, p 50

17. Kim TY, Kim SB, Yoo SM, Kim HR, Lee SH (2004) Study on applications of over-produced rice to manufacture traditional rice wine. RDA, ISSN 1225-6218, p 215-226
18. Graham HF (1993) Wine microbiology and biotechnology. Harwood Academic Publishers, Langhorne, PA, USA, p 400-401

19. Joyeux A, Lafon-Lafourcade S, Ribereau-Gayon P (1984) Evolution of acetic acid bacteria during fermentation and storage of wine. Appl Environ Microbiol, 48, 153-156

20. Kong MH, Jeong ST, Yeo SH, Choi JH, Choi HS, Han GJ, Jang MS, Chung IM (2011) Determination of ginseng Yakju quality using different percentages and application dates of ginseng. J East Asian Soc Diet Life, 21, 207-214

21. Hwang SW, Park HD (2010) Properties of red wine fermented using freeze-concentrated muscat bailey a grape juice. Korean J Food Preserv, 17, 807-813

22. Jeon JA, Kim MS, Ko JY, Jeong ST (2017) Quality characteristics of Yakju fermented with paddy rice (Byeo) Nuruk Yakju. J East Asian Soc Diet Life, 27, 159-167

23. Kim CJ (1963) Studies on the quantitative changes of organic acid and sugars during the fermentation of Takju. Korean J Appl Biol Chem, 4, 33-42

24. Kim TY (1998) Industrialization and quality improvement of traditional alcoholic beverages and Nuruk brewed. Ministry of Science and Technology, Seoul, Korea, p 445

25. Jung JH, Jung ST (1987) Odor threshold and agreeability of aroma components of Yakju. Korean J Agric Chem, 30, 272-277 